\title{
MORPHACTIN STIMULATES STEM ELONGATION AND THICKENING IN DECAPITATED SHOOTS OF Bryophyllum calycinum Salisb.
}

\author{
Kensuke Miyamoto ${ }^{1}$, Agnieszka Marasek-Ciołakowska², Justyna Góraj², \\ Elżbieta Węgrzynowicz-Lesiak², Junichi Ueda ${ }^{3}$, Marian Saniewski²
}

\author{
${ }^{1}$ Faculty of Liberal Arts and Sciences, Osaka Prefecture University, 1-1 Gakuen-cho, Naka-ku, Sakai, Osaka 599-8531, Japan \\ ${ }^{2}$ Research Institute of Horticulture, Konstytucji 3 Maja 1/3, 96-100 Skierniewice, Poland \\ ${ }^{3}$ Graduate School of Science, Osaka Prefecture University, 1-1 Gakuen-cho, Naka-ku, Sakai, Osaka 599-8531, Japan \\ e-mail:miyamoto@las.osakafu-u.ac.jp
}

Received: 10.03 .2013

\begin{abstract}
Morphactin, methyl 2-chloro-9-hydroxyfluorene-9-carboxylate (IT 3456), is a synthetic growth regulator with a unique action affecting various morphogenetic and physiological processes in plants, and has been characterized as a specific inhibitor of auxin polar transport. Morphactin applied at the last internode in decapitated shoots of Bryophyllum calycinum substantially stimulated elongation and thickening of the internode. Benzyladenine applied alone little affected stem elongation and thickening. Simultaneous application of benzyladenine and morphactin showed a synergistic effect on thickening, while it did not on elongation. These results suggest that morphactin translocated basipetally from the top of the treated internode inhibits auxin polar transport from the internode, resulting in the accumulation of endogenous auxin for elongation and thickening in the treated internode of decapitated shoots of Bryophyllum calycinum.
\end{abstract}

Key words: Bryophyllum calycinum, elongation, internode, methyl 2-chloro-9-hydroxyfluorene-9-carboxylate, thickening, morphactin

\section{INTRODUCTION}

Morphactins, consisting of methyl 2-chloro-9hydroxyfluorene-9-carboxylate (morphactin IT 3456) and its derivatives, are synthetic growth regulators with a unique kind of action that greatly affects various morphogenetic and physiological processes in plants (S chneider, 1970). Since morphactins have been characterized as specific inhibitors of auxin polar transport (Khan, 1967; Krelle and Libbert, 1968; Tognoni and Alpi, 1969; Parups, 1970; Schneider, 1970; Naqvi, 1972; Bridges and Wilkins, 1973; Kaldewey et al. 1973; Gaither
1975; Gagianas and Berg, 1977; Katekar and Geissler, 1980; Tamimi and Firn, 1985), the mode of action of morphactins to influence various morphological processes in growth and development has been considered to be closely related to auxin.

A morphactin-related compound, 9-hydroxyfluorene-9-carboxylic acid (HFCA), has been reported to show the unique physiological effect on flower formation in Arabidopsis thaliana. The pin-formed and pinoid mutants in Arabidopsis, which are flower mutants normally showing a unique structure with no flower in the inflorescence axis, have been shown to have reduced activity of auxin polar transport in the inflorescence axis ( $\mathrm{O} \mathrm{k}$ a d a et al. 1991; U e d a et al. 1992; B ennett et al. 1995; O ka et al. 1998), and that the application of HFCA as well as $N$-(1-naphtyl) phtalamic acid (NPA) and 2,3,5-triiodobenzoic acid (TIBA) to the wild type of Arabidopsis induced malformations mimicking the pin-formed mutant $(\mathrm{O} \mathrm{k}$ a d a and Shimura, 1994; O k a et al. 1999). Compression wood, which is normally produced on the lower side of inclined stems and branches as a response to normal gravitropic conditions in vertically growing shoots of various coniferous (gymnosperm) species, was induced by the application of morphactins. The morphactin-induced compression wood is probably caused by the differential redistribution or accumulation of endogenous auxin (indole-3-acetic acid: IAA) between the lower and upper sides of branches in the affected part of the shoot (W e sting, 1965, 1968; S molińs ki et al. 1972, 1973; Phelps et al. 1974, 1977; Y a m a g u chi et al. 1983), since the application of IAA resulted in compression wood formation. The formation of tension wood, which is produced on 
the upper side in inclined stems and branches of angiosperms as a response to natural gravitropic conditions, on the upper side of bent shoots of Aesculus hippocastanum was inhibited by morphactins. The pattern of wood differentiation was changed, altering it to favor vessel-type cell formation (S m o li ń s k i et al. 1974). It has also been reported that morphactins dispensed through the shoot apex induced diverse malformations in various species of Kalanchoe, the effect being freely transmitted to newly emerging axially branches as well as across leaf lamina differentiating epiphyllous buds (S awhney and Mahajan, 1995). These results mentioned above support the possible mode of action of morphactins to influence various morphogenetic processes in growth and development that are closely related to auxin transport.

Morphactins have been found to influence photo- and gravitropic responses ( $\mathrm{K} \mathrm{h}$ a n , 1967; $\mathrm{S} \mathrm{c} \mathrm{h} \mathrm{n} \mathrm{e} \mathrm{-}$ $\mathrm{id} \mathrm{e} \mathrm{r} \mathrm{,} \mathrm{1970)} \mathrm{in} \mathrm{which} \mathrm{auxin} \mathrm{transport} \mathrm{is} \mathrm{essential} \mathrm{for}$ differential distribution of auxin resulting in differential cell elongation as well. In tulips, stem growth induced by IAA $(0.1 \%$, w/w in lanolin) applied on the top internode after excision of the flower bud and removal of all leaves was greatly inhibited by morphactin IT $3456\left(0.2 \%, \mathrm{w} / \mathrm{w}\right.$ in lanolin) applied on the $4^{\text {th }}$, $3^{\text {rd }}, 2^{\text {nd }}$, and $1^{\text {st }}$ internode. The inhibitory effect of morphactin promoted by IAA was restored by additional application of IAA below the place treated with morphactin. Morphactins also inhibited the growth of all internodes induced by the flower bud in the absence of leaves (S a niewski et al. 1999). On the other hand, recently we have also found that morphactins applied above the $3^{\text {rd }}$ internode substantially induced the growth of the $4^{\text {th }}$ internode in decapitated tulips and that there was significant accumulation of IAA in the $4^{\text {th }}$ internode (Ueda et al. 2012). These results suggest that morphactins influence cell elongation of stems by affecting auxin distribution in stems.

In the present study, we report that morphactin (morphactin IT 3456) substantially stimulated elongation and great thickening of the last internode in decapitated plants of Bryophyllum calycinum, most probably through inhibiting auxin polar transport to the lower part of the shoot. Since the synergistic action of morphactin with endogenous auxin and cytokinins on cambial activity has been suggested ( $\mathrm{S}$ a n i e w s ki et al. 1977), simultaneous application of cytokinin with morphactin was also examined. The possible role of morphactins to induce elongation and great thickening of stems is discussed.

\section{MATERIALS AND METHODS}

Two to three month-old plants of Bryophyllum calycinum Salisb. propagated from epiphyllous buds arising in the marginal notches of the excised leaves were used for the experiments (Fig. 1 a). The apical part of growing plants was excised below the second node from the apex and treated with lanolin in the place of the removed shoot. Then, the following treatments with lanolin paste were made near the top of the decapitated growing plants as a ring about $2 \mathrm{~mm}$ wide: lanolin only (control), morphactin (morphactin IT 3456) $0.2 \%$, $\mathrm{w} / \mathrm{w}$, benzyladenine $0.2 \%$, w/w, and a mixture of morphactin and benzyladenine at the same concentrations as applied alone. Every experiment was repeated three times with a minimum of 10 plants in each treatment. During the duration of the experiments, measurements were made of the length and thickening of treated internodes and below treated internodes.

For histological observation of the shoots, pieces of $5 \mathrm{~mm}$ in length were cut off from the middle of the highest internode in decapitated plants 20 days after chemical treatments. Both for control and treated material, tissues were obtained from 5 shoots. The material was fixed in chromic acid-acetic acid-formalin (CrAF) solution for 24 hours at room temperature, dehydrated through alcohol series and embedded in paraffin. Transverse sections, $8 \mu \mathrm{m}$ thick, were cut with a rotary microtome (Leica, Germany) and stained with safranine-fast green. The sections were mounted in Canada balsam and observed under a light microscope (Microphot-FXA, Nikon, Japan). The selected sections were photographed with a camera attached to the microscope on Fujicolour 100 ISO negative film.

\section{RESULTS}

Figure 1 and Table 1 show the effect of morphactin IT3456 (morphactin) and cytokinin on shoot growth of decapitated Bryophyllum calycinum. It was found that in the decapitated shoot of Bryophyllum calycinum on August 11 the length of the last internode did not elongate more in control until October 12, but sprouting of axillary buds was visible (Fig. $1 \mathrm{a}, \mathrm{b}$ ). The application of cytokinin insted of cytokinin, benzyladenine affected little the length of the last internode as well as sprouting of axiallry buds (Fig. $1 \mathrm{c}$; Table 1).

On the other hand, after treatment of the last internode with morphactin or the mixture of morphactin with benzyladenine the elongation of the internode was observed (Fig. 1 c, e; Table 1), although no additive or synergistic effect on stem elongation was observed. The treatment with morphactin or the mixture of morphactin with benzyladenine induced strong thickening of the treated internode, the morphactin-induced thickening being slightly but significantly stimulated by the simultaneous application of benzyladenine (Table 1). The diameter of the morphactin-treated internode was ca. $180 \%$ of the control.

Figure 2 shows the histological study of the effect of morphactin on shoot growth of decapitated 
Bryophyllum calycinum. Shoots of control plants were characterized by the presence of a ring of vascular tissue with xylem and phloem separated by a cambial zone (Fig. 2a). The cortex and pith contained large, vacuolated pa- renchyma cells. Compared with the control, the material treated with morphactin at $0.2 \%, \mathrm{w} / \mathrm{w}$ had a significantly wider cambial zone and a zone of secondary xylem, resulting in thickening of the internode (Fig. 2b, c).
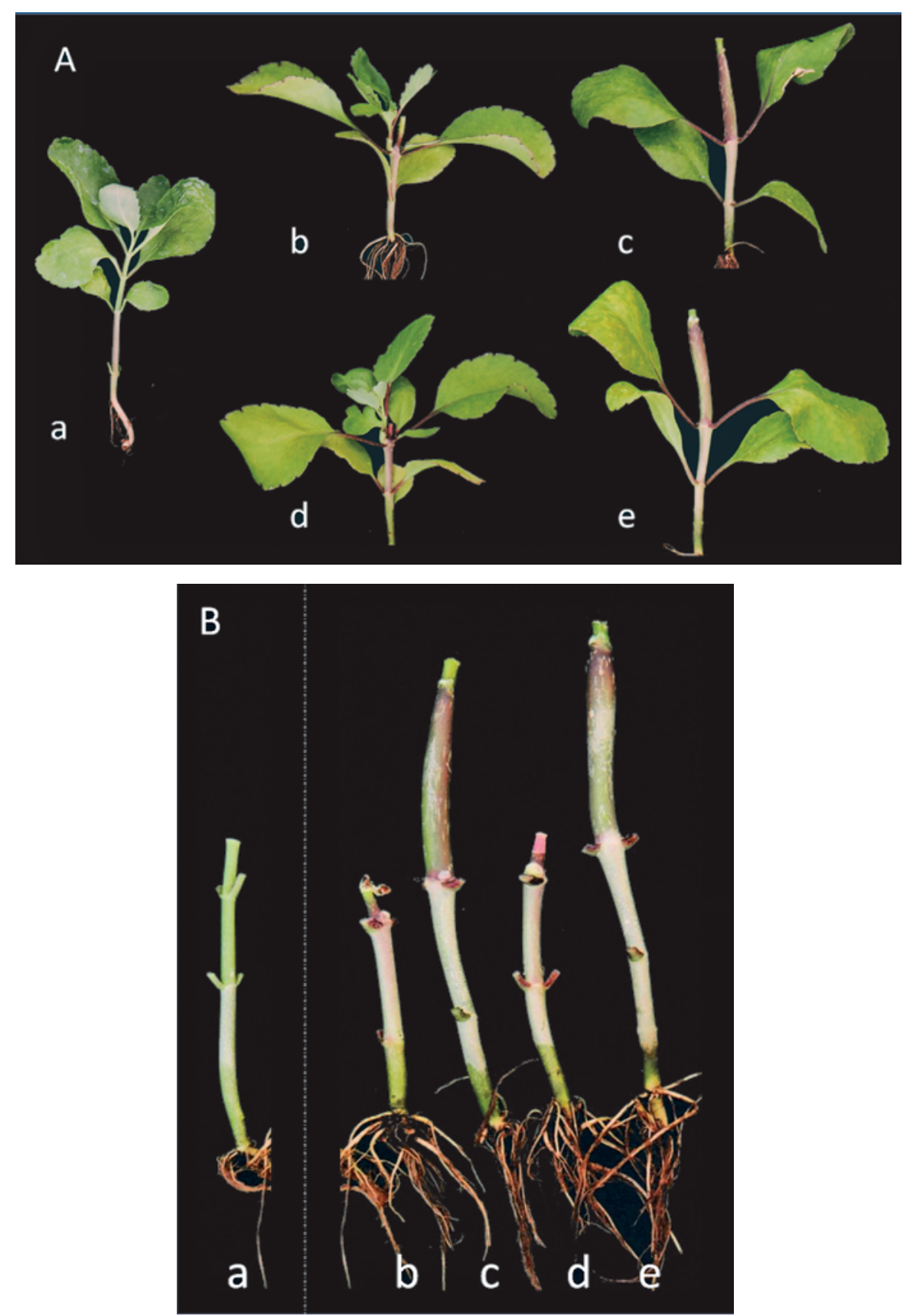

Fig. 1. The effect of morphactin IT3456, benzyladenine and their mixture, all used at a concentration of $0.2 \%$, applied on the last internode of decapitated shoots of Bryophyllum calycinum on the elongation and thickening of treated internodes; treatments made on August 11 (a), photographed on October 15

A: Picture of treatment $a, b, c, d$ and e.

a) initial plants on the day of treatment (August 11);

b) control plants, treated with lanolin only; the upper part of the last internode abscised and sprouting of axillary bud is visible;

c) morphactin; the elongation and thickening of the treated internode can be observed;

d) benzyladenine; the upper part of the last internode abscised and sprouting of axillary bud is visible;

e) morphactin + benzyladenine; the elongation and thickening of the treated internode can be observed.

B: Picture of initial treatment a, and treatment b, c, d and e after removal of all leaves and axillary buds in the treatments 


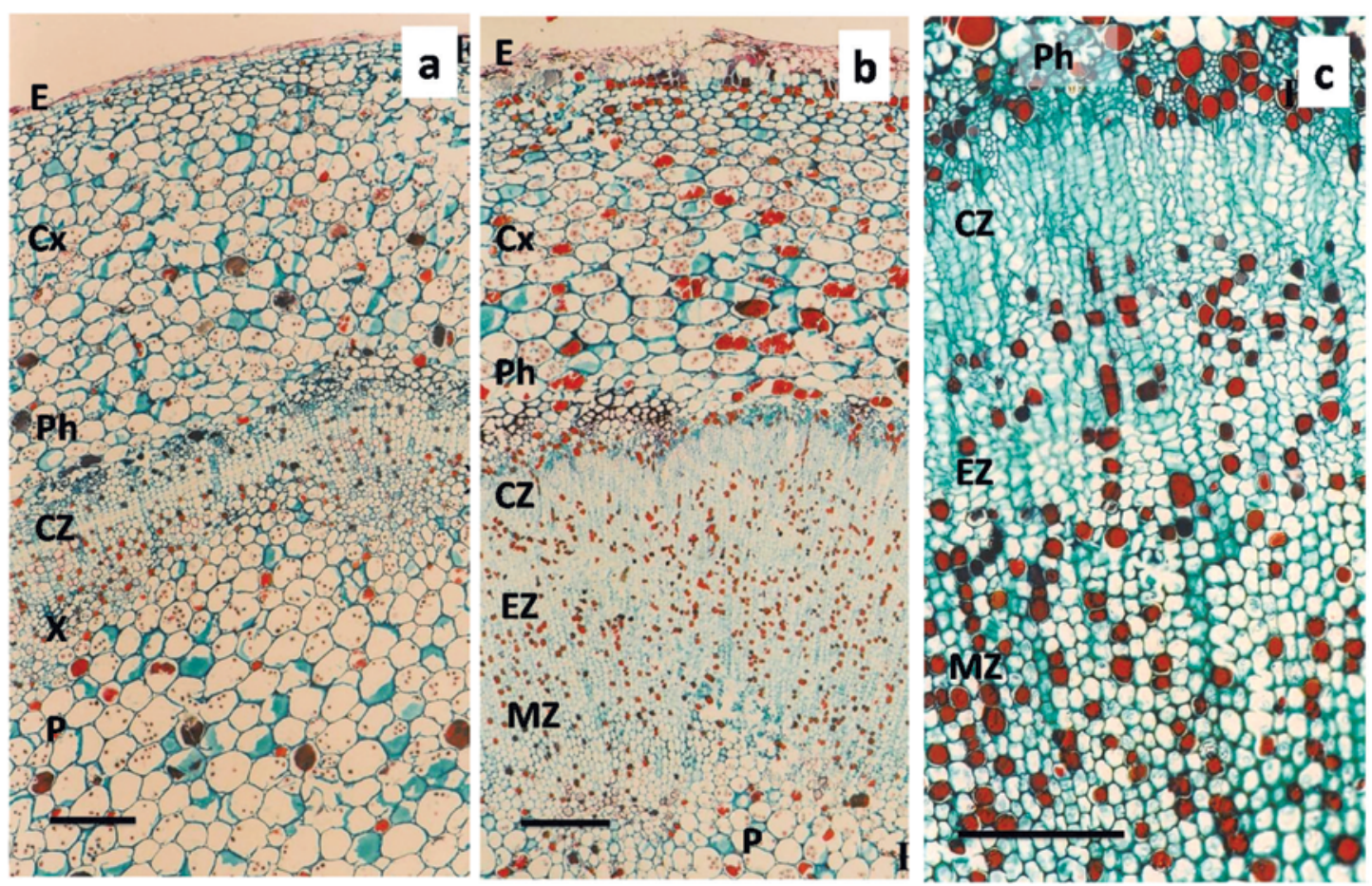

Fig. 2. The effect of morphactin IT3456 on the histological changes (transections) in cambial activity, xylem, phloem and cortex formation in the treated internode in the decapitated stem of Bryophyllum calycinum

a) control; $\mathrm{Bar}=150 \mu \mathrm{m}$.

b) and c) treatment with morphactin (see Fig. 1); Bar $=150 \mu \mathrm{m}$.

c) Enlarged cambial zone and cambial derivatives on the phloem and xylem sides

$\mathrm{Cx}$, cortex; CZ, cambial zone; E, epidermis; EZ, expansion zone; MZ, maturation zone and mature xylem; X, xylem; $\mathrm{P}$, pith; $\mathrm{Ph}$, phloem;

Table 1

The effect of morphactin IT3456 (Morph.), benzyladenine (BA) and their mixture on stem elongation and thickening in decapitated shoots of Bryophyllum calycinum

\begin{tabular}{|c|c|c|c|c|}
\hline \multirow{3}{*}{ Treatments } & \multicolumn{2}{|c|}{ Length of treated internode $(\mathrm{mm})$} & \multirow{3}{*}{$\begin{array}{c}\text { Increase } \\
\text { in internode length } \\
(\mathrm{mm})\end{array}$} & \multirow{3}{*}{$\begin{array}{c}\text { Diameter of } \\
\text { treated internode }(\mathrm{mm})\end{array}$} \\
\hline & August 11 & October 12 & & \\
\hline & \multicolumn{2}{|c|}{ (time of treatment) } & & \\
\hline Control & $29.5 \mathrm{a}$ & $31.4 \mathrm{a}$ & $1.9 \mathrm{a}$ & $4.9 \mathrm{a}$ \\
\hline Morph. $0.2 \%$ & $34.4 \mathrm{~b}$ & $64.1 \mathrm{~b}$ & $29.7 \mathrm{~b}$ & $8.5 \mathrm{~b}$ \\
\hline BA $0.2 \%$ & $34.5 \mathrm{~b}$ & $36.6 \mathrm{a}$ & $2.1 \mathrm{a}$ & $5.3 \mathrm{a}$ \\
\hline Morph. $0.2 \%+$ BA $0.2 \%$ & $34.0 \mathrm{~b}$ & $60.2 \mathrm{~b}$ & $26.2 \mathrm{~b}$ & $9.7 \mathrm{c}$ \\
\hline
\end{tabular}

\section{DISCUSSION}

Since morphactins have been characterized as specific inhibitors of auxin polar transport, it is possible that morphactins interfere with many processes in plant growth and development relating to auxin polar transport. As shown in Figure 1 and Table 1, elongation growth of the last internode in a decapitated shoot of Bryophyllum calycinum was substantially stimulated by the application of morphactin IT3456 (morphactin). The mode of action of morphactin stimulating the elongation of internodes in Bryophyllum calycinum is unclear yet. However, the stimulatory effect of morphactin on compression wood formation and the inhibitory effect on tension wood formation seem to be caused by some inhibitory action of morphactin on longitudinal and transverse transport of endogenous auxin as well as by a synergistic action of morphactin with endogenous auxin and cytokinins on cambial activity (S a n i e w s k i et al. 1977). Recently, we have found that morphactin significantly stimulated the growth of the $4^{\text {th }}$ internode in growing tulips after removal of the flower bud when it was applied above the $3^{\text {rd }}$ node or on the top of the $4^{\text {th }}$ internode via 
inhibiting auxin polar transport from the $4^{\text {th }}$ internode to the lower internodes ( $\mathrm{U}$ e $\mathrm{d}$ a et al. 2012). A significant accumulation of endogenous levels of IAA in the $4^{\text {th }}$ internode after treatment with morphactin has also been demonstrated ( $\mathrm{U}$ e d a et al. 2012). Morphactin is believed to be translocated in plants basipetally as well as acropetally through both sieve tubes and xylem elements (Ne u mann et al. 1977; S undberg et al. 1994). It has been demonstrated that morphactin and some other auxin transport inhibitors induced parthenocarpy in cucumber by rapidly blocking the natural outward flow of auxin from the ovary, thereby resulting in an accumulation of auxin within the ovary sufficient to trigger parthenocarpy (B e y e $\mathrm{r}$ and $\mathrm{Q} u$ e b e d e a u x , 1974). Further study is required to determine endogenous levels of IAA in decapitated shoots after treatment with morphactin in Bryophyllum calycinum.

As shown in Figure 2, morphactin treatment significantly induced histological changes such as a wider cambial zone and wider zone of secondary xylem. It has been reported that morphactin increased the cambial activity and irregular differentiation of xylem elements in Sterculia urens Roxb. (Malvaceae) (P a te 1 and S e ti a, 1979). Morphactin treatments have been reported to increase stem diameter of guayule (Parthenium argentatum) (Dierig and $\mathrm{Backhaus,}$ 1990), Pinus radiata, Eucalyptus globules and olives (B a ckhau s et al. 1976; D os s et al. 1977), when applied as a bark band, the thickening being considered to be mostly associated with the stimulation of cambial activity. These facts suggest that the drastic increase in the diameter of the internode treated with morphactin in Bryophyllum calycinum is due to an increase in cambial activity resulting in wider cambial zone and wider zone of secondary xylem.

As mentioned above, the stimulatory effect of morphactin on compression wood formation and the inhibitory effect on tension wood formation are probably caused by the synergistic action of morphactin with endogenous auxin and cytokinins on cambial activity (S a n i e w s ki et al. 1977). In the internodes of Bryophyllum calycinum, benzyladenine alone had a little effect on thickening, while together with morphactin it slightly but significantly enhanced the thickening of the internode (Table 1). This suggests that the morphactin-induced increase in cambium activity and the stimulation of internode elongation in Bryophyllum calycinum are mainly controlled by the accumulation of endogenous IAA.

The cambium in the treated material consisted of many layers of irregular cells with well visible nucleoli. The walls of many cambial cells were destroyed, which may be an artifact caused by treatment of the fixation procedure. Cambial derivatives on the xylem side could be divided into the expansion zone with layers of cells irregular in shape and the maturation zone and mature xylem whose cells were characterized by more regular, round shapes and thicker wall cells. The size of parenchyma cells and the number of layers in the cortex and pith seemed to be unchanged, although no quantitative determinations were attempted.

As already suggested by $\mathrm{Fu} \mathrm{j} \mathrm{it} \mathrm{a} \mathrm{and} \mathrm{S}$ y $\mathrm{no}$ (1996), the detailed mechanism of morphactin IT3456 still remains unclear whether or how the blockage of auxin polar transport by this inhibitor is involved in the effect of this inhibitor on physiological and developmental processes in plants. The binding site of morphactins has also been unclear yet, morphactins have however been shown to bind to the NPA receptor suggesting that morphactin inhibits auxin polar transport by the same mechanism as NPA ( $\mathrm{Sus} \mathrm{s} \mathrm{man}$ and Golds mith, 1981; Th o m s on and Le o p old, 1974). It is believed that morphactin is translocated in plants basipetally as well as acropetally through both sieve tubes and xylem elements ( $\mathrm{N}$ e u man n et al. 1977; S und be rg et al. 1994). It is possible that morphactin is translocated basipetally from the top of the treated internode of decapitated Bryophyllum calycinum and inhibits auxin polar transport from the internode and, in consequence, the accumulation of endogenous auxin takes place in the treated internode, and finally elongation and thickening of the internode was observed. It should also be mentioned that the activity of morphactin is multidirectional and some other properties of morphactin may have influenced elongation and thickening in decapitated shoots of Bryophyllum calycinum.

\section{Acknowledgments}

This work was partially supported by JSPS KAKENHI (Grant No.1281205900 to KM and Grant No. 23510260 to JU).

\section{Authors' contributions}

The following declarations about authors' contributions to the research have been made: designing the experiments: MS, KM, JU; field work: AM-C, JG, EW-L; histological analysis: AM-C, JG, EW-L; writing of the manuscript: KM, MS, JU.

\section{REFERENCES}

Backhaus R.A., Sachs R.M., Hield H.Z. 1976. Tree growth inhibition by bark application of morphactin. HortScience, 11: 578-580.

Bennet S.R.M., Alvarez J., Bossinger G., Smyth D.R. 1995. Morphogenesis in pinoid mutant of Arabidopsis thaliana. Plant J., 8: 505-520.

Beyer E.M., Jr., Quebedeaux B. 1974. Parthenocarpy in cucumber: Mechanism of action of auxin transport inhibitors. J. Amer. Soc. Hort. Sci. 99: 385-390. 
Bridges I.G., Wilkins M.B. 1973. Effects of morphactin on indole-3yl-acetic acid transport, growth and geotropic response in cereal coleoptiles. J. Exp. Bot. 24: $711-723$

Dierig D.A., Backhaus R.A. 1990. Effects of morphactin and DCPTA on stem growth and bioinduction of rubber in guayule. HortSci. 25: 531-533.

Doss, R.P., Neumann, P.M., Backhaus, R.A., Sachs, R.M. 1977. Bark banding of Pinus radiate with morphactin (IT3456): Influence on trunk anatomy, assimilate transport and growth. Physiol. Plant. 39: $280-284$

Fujita H., Sy no K. 1996. Genetic analysis of the effects of polar auxin transport inhibitors on root growth in Arabidopsis thaliana. Plant Cell Physiol. 37: 1094 1101.

Gagianas A.A., Berg A.R. 1977. The effect of morphactin (methyl 2-chloro-9-hydroxyfluorene-9-carboxylate) on basipetal transport of indole-3-ylacetic acid in hypocotyl sections of Phaseolus vulgaris L. Ann. Bot. 41: 1135-1148.

Gaither D.H. 1975. Auxin and the response of pea roots to auxin transport inhibitors: morphactin. Plant. Physiol. 55: 1082-1086.

Kaldewey H., Ginkel U., Lehmann I., Seiwert R. 1973. Transport and immobilization of indoleacetic acid as affected by morphactins. I. Time course of auxin transport in sections excised from different hypocotyl regions of light-grown seedlings of Citrullus edulis. Proc. Res. Inst. Pomol., Skierniewice, Poland, Ser. E. 3: 215-226.

Katekar G.F., Geissler A.E. 1980. Auxin transport inhibitors. IV. Evidence of a common mode of action for a proposed class of auxin transport inhibitors: The phytotropins. Plant Physiol. 66: 1190-1195.

Khan A.A. 1967. Physiology of morphactins: effect on gravi- and photo-response. Physiol. Plant. 20: 306-313.

Krelle E., Libbert E. 1968. Inhibition of the polar auxin transport by a morphactin. Planta, 80: 317-320.

Naqvi S. 1972. The effect of morphactin on the kinetics of indole-3yl-acetic acid-2- ${ }^{14} \mathrm{C}$ transport in Zea mays $\mathrm{L}$. coleoptile segments. J. Exp. Bot. 23: 763-767.

Neumann P.M., Doss R.P., Sachs R.M. 1977. A new laboratory method used for investigating the uptake, translocation and metabolism of bark banded morphactin by trees. Physiol. Plant. 39: 248-251.

Oka M., Miyamoto K., Okada K., Ueda J. 1999. Auxin polar transport and flower formation in Arabidopsis thaliana transformed with indoleacetamide hydrolase (iaaH) gene. Plant Cell Physiol. 40: 231-237.

Oka M., Ueda J., Miyamoto K., Okada K. 1998. Activities of auxin polar transport in inflorescence axes of flower mutants of Arabidopsis thaliana: Relevance to flower formation and growth. J. Plant Res. 111: $407-410$

Okada K., Shimura Y. 1994. Genetic analyses of signalling in flower development using Arabidopsis. Plant Mol. Biol. 26: 1357-1377.
Okada K., Ueda J., Komaki K.K., Bell C.J., Shimura Y. 1991. Requirement of the auxin polar transport system in early stages of Arabidopsis floral bud formation. Plant Cell, 3: 677-684.

Parups E.V. 1970. Effect of morphactin on the gravimorphism and the uptake, translocation and spatial distribution of indole-3-yl-acetic acid in plant tissues in relation to light and gravity. Plant Physiol. 23: 1176-1186.

Patel J.D., Setia R.C. 1979. Effect of morphactin-EMD 7301 on cambial activity and xylogenesis in Sterculia urens Roxb. Indian J. Exper. Biol. 17: 350-353.

Phelps J.E., McGinnes E.A., Jr., Smoliński M., Saniewski M., Pieniążek J. 1977. A note on the formation of compression wood induced by morphactin IT 3456 in Thuja shoots. Wood and Fiber, 8: 223-227.

Phelps J.E., Saniewski M., Smoliński M., Pieniążek J., McGinnes E.A., Jr. 1974. A note on the structure of morphactin-induced wood in two coniferous species. Wood and Fiber, 6: 13-17.

Saniewski M., Okubo H., Puchalski J. 1999. Effect of morphactin on stem growth in relation to auxin in precooled rooted tulip bulbs. Acta Physiol. Plant. 21: 167-174. http://dx.doi.org/10.1007/s11738-999-0072-2

Saniewski M., Smoliński M., Pieniążek J., Phelps J.E., McGinnes E.A., Jr. 1977. Studies on the effect of morphactin on cambial activity and wood differentiation in some hardwood and softwood species. Proc. Second Inter. Symp. on Plant Growth Regulators, Sofia, Bulgaria: 477-480.

Sawhney S., Mahajan A. 1995. Morphactin-induced malmorphogenetic effect and its transmission in Kalanchoё. Biol. Plant. 37: 443-447.

Schneider G. 1970. Morphactins: physiology and performance. Annu. Rev. Plant Physiol. 21: 499-536.

Smoliński M., Pieniążek J., Saniewski M. 1973. Induction of compression-like wood by morphactin in vertically growing shoots of Pinus silvestris L. Proc. Res. Inst. Pomol., Skierniewice, Poland, Ser. E, 3: 553-558.

Smoliński M., Saniewski M., Pieniążek J. 1972. The effect of morphactin IT 3456 on cambial activity and wood differentiation in Picea excelsa. Bull. Acad. Pol. Sci., Ser. Sci. Biol. 20: 431-435.

Smoliński M., Saniewski M., Pieniążek J. 1974. The suppression of tension wood formation in bent shoots of Aesculus hippocastanum L. by morphactin IT 3456. Bull. Acad. Polon. Sci., Ser. Sci. Biol. 22: 809-812.

Sundberg B., Tuominen H., Little C.H.A. 1994. Effects of the indole-3-acetic acid (IAA) transport inhibitors $N$-1-naphthylphtalamic acid and morphactin on endogenous IAA dynamics in relation to compression wood formation in 1-year old Pinus sylvestris (L.) shoots. Plant Physiol. 106: 469-476.

Sussman M.R., Goldsmith M.H.M. 1981. Auxin uptake and action of N-1-naphthylphthalamic acid in corn coleoptiles. Planta, 151: 15-25. 
Tamimi S., Firn R.D. 1985. The basipetal auxin transport system and the control of cell elongation in hypocotyls. J. Exp. Bot. 36: 955-962.

Thomson K.-S., Leopold A.C. 1974. In-vitro binding of morphactins and 1-N-naphthylphthalamic acid in corn coleoptiles and their effects on auxin transport. Planta, 115: 259-270.

Tognoni F., Alpi A. 1969. Morphactins, auxin transport and apical dominance in Pisum sativum. Ber. Deut. Bot. Ges. N.F. 3: 53-60.

Ueda J., Góraj J., Węgrzynowicz-Lesiak E., Miyamoto K., Saniewski M.2012. Morphactin substantially induced the fourth internode growth in decapitated tulips: Relevance to endogenous levels of indole-3-acetic acid. J. Fruit and Ornamental Plant Res., 20: $161-171$.

Ueda J., Okada K., Komaki K.K., Kato J., Shimura Y. 1992. Auxin polar transport system and flower formation in Arabidopsis. Proceedings Nineteenth Annual. Meeting Plant Growth Regulator Society of America. 175-180.

Westing A.H. 1965. Formation and function of compression wood in gymnosperms. Bot. Rev. 31: 381-480.

Westing A.H. 1968. Formation and function of compression wood in gymnosperms. II. Bot. Rev. 34: 51-78.

Yamaguchi K., Shimaji K., Itoh T. 1983. Simultaneous inhibition and induction of compression wood formation by morphactin in artificially inclined stems of Japanese larch (Larix leptolepis Gordon). Wood Sci. Technol. 17: 81-89.

\section{Morfakyna stymuluje wzrost wydłużeniowy i grubość łodygi w dekapitowanych roślinach Bryophyllum calycinum Salisb.}

\section{Streszczenie}

Morfaktyna, kwas metylo 2-chloro-9-hydroksyfluoreno-9-karboksylowy (IT 3456), jest syntetycznym regulatorem wzrostu o specyficznym działaniu powodującym zakłócenie wielu morfogenetycznych i fizjologicznych procesów w roślinach, jest specyficznym inhibitorem polarnego transportu auksyn. Morfakyna zastosowana na ostatnie międzywęźle w dekapitowanym pędzie Bryophyllum calycinum silnie stymuluje wydłużenie i zgrubienie tego międzywęźla. Benzyloadenina podana w podobny sposób jak morfaktyna nie powodowała istotnych zmian $\mathrm{w}$ porównaniu do roślin kontrolnych. Łączne traktowanie ostatniego międzywęźla po dekapitacji roślin morfaktyną i benzyloadeniną powodowało synergistyczny wpływ tylko na zgrubienie łodygi w porównaniu z traktowaniem samą morfaktyną. Otrzymane wyniki wskazują, że morfaktyna jest przemieszczana bazypetalnie $\mathrm{z}$ wierzchołka traktowanego międzywęźla i hamuje polarny transport w tym międzywęźlu, w wyniku tego następuje akumulacja auksyny w tym międzywęźlu powodując wydłużanie i grubienie traktowanego międzywęźla w dekapitowanych roślinach Bryophyllum calycinum. 
